\title{
PENGARUH STRUKTUR KEPEMILIKAN SAHAM, KEBIJAKAN DIVIDEN DAN KEBIJAKAN HUTANG TERHADAP NILAI PERUSAHAAN (Studi Pada Perusahaan Yang Terdaftar di BEI)
}

\author{
Herni Ali HT, Miftahurrohman \\ UIN Syarif Hidayatullah Jakarta, CBC PT SIEMENS Indonesia
}

\begin{abstract}
Impact of Ownership Structure, Dividend Policy, and Debt Policy On The Value of The Firms: Studied at Listed Firm in Indonesia Stock Exchange. The main objective of this study is to examine the impact of ownership structure, dividend policy, debt policy on the value of the firms in Indonesian Stock Exchange. Data used in this research is financial data in the form financial statements of public companies listed in Indonesian Stock Exchange. The statistical method used to test the hypothesis is Structural Equation Modeling (SEM) analysis. The results of this study shown that: ownership structure has a significant positive influence to dividend policy. Ownership structure significant negative influence to debt policy. Ownership structure have no influence to value of the firms. Dividend policy significant negative influence to debt policy. Dividend policy have no influence to value of the firms. Debt policy significant positive influence to value of the firms.
\end{abstract}

Keywords: ownership structure, dividend policy, debt policy, value of the firms

Abstrak. Pengaruh Struktur Kepemilikan Saham, Kebijakan Dividen, dan Kebijakan Hutang Terhadap Nilai Perusahaan: Studi Pada Perusahaan Yang Terdaftar di Bursa Efek Indonesia. Tujuan utama dari penelitian ini ialah untuk menguji pengaruh struktur kepemilikan saham, kebijakan dividen, dan kebijakan hutang terhadap nilai perusahaan yang terdaftar di Bursa Efek Indonesia. Data yang digunakan ialah data keuangan yang berasal dari laporan keuangan perusahaan publik yang terdaftar di Bursa Efek Indonesia. Metode analisis yang dipergunakan untuk menguji hipotesis ialah menggunakan Structural Equation Modeling (SEM). Hasil yang ada menunjukkan bahwa struktur kepemilikan memiliki pengaruh yang positif terhadap kebijakan dividen. Struktur kepemilikan memiliki pengaruh yang negatif terhadap kebijakan hutang. Struktur kepemilikan saham tidak memiliki pengaruh terhadap nilai perusahaan. Kebijakan dividen memiliki pengaruh negatif terhadap kebijakan hutang. Kebijakan dividen tidak berpengaruh terhadap nilai perusahaan. Kebijakan hutang memiliki pengaruh terhadap nilai perusahaan.

Kata Kunci: struktur kepemilikan saham, kebijakan dividen, kebijakan hutang, nilai perusahaan 


\section{PENDAHULUAN}

Dalam literatur keuangan (Financial literature), tujuan utama dari sebuah perusahaan adalah untuk meningkatkan nilai perusahaan melalui peningkatan kemakmuran pemilik atau para pemegang saham (Brigham dan Houston, 2009). Kemakmuran pemegang saham tercermin dalam harga saham di pasar modal. Semakin tinggi harga saham menunjukan kesejahteraan pemilik perusahaan semakin meningkat (A.W. Djabid, 2009). Namun tidak jarang pihak manajemen atau manajer sebagai pengelola perusahaan mempunyai tujuan lain yang mungkin bertentangan dengan tujuan utama perusahaan tersebut, sehingga mucul konflik kepentingan di antara pihak manajemen dalam hal ini yaitu manajer (agen) dengan para pemegang saham (principal) sehingga menimbulkan apa yang di sebut dengan masalah keagenan (agency problems) (Brealey et al., 2008).

Masalah keagenan tentunya akan menimbulkan kerugian. Karena konflik kepentingan antara agen dan pemilik ini dapat menimbulkan biaya yang di sebut dengan biaya keagenan (Indra Surya dan Ivan Yustiavandana, 2008). Jensen dan Meckling (1976) dalam Etty M. Nasser (2008) menyatakan ada tiga biaya keagenan, antara lain: pertama, monitoring cost (biaya monitoring), yaitu biaya untuk membatasi aktivitas yang dilakukan agen. Kedua, bonding cost (biaya hutang), yaitu biaya karena penggunaan hutang oleh manajemen (agency) dan pengeluaran karena hilangnya keindependenan atau efisiensi (residual loss). Ketiga, biaya ini tidak memiliki pengaruh langsung, biaya ini merupakan akibat berkurangnya kesejahteraan yang seharusnya diterima perusahaan.

Dalam kontek agency cost model salah satu upaya yang dapat digunakan untuk mengurangi agency problem dan agency cost adalah dengan meningkatkan kepemilikan, baik kepemilikan oleh manajerial (insider ownership) ataupun kepemilikan oleh institusional (institutional ownership). (Farah Margaretha dan Andhini Asmariani, 2009). Jensen dan Meckling (1976) dalam Bambang Sugeng (2009) mengemukakan bahwa agency cost akan rendah di dalam perusahaan dengan kepemilikan yang tinggi, karena hal ini memungkinkan adanya penyatuan antara kepentingan pemegang saham 
dengan kepentingan manajer yang dalam hal ini manajer selain sebagai agent sekaligus sebagai principal.

Fenomena yang terjadi pada perusahaan-perusahaan go public di Indonesia, dimana tingkat kepemilikan oleh insider ownership dalam perusahaan sangatlah kecil, dari sampel perusahaan yang digunakan dalam penelitian ini, diperoleh data rata-rata insider ownership berjumlah kecil yaitu kurang dari 5\% sehingga dengan kondisi seperti ini kemungkinan penyatuan antara kepentingan pemegang saham dengan kepentingan manajerial seperti yang diungkapkan oleh Jensen dan Meckling (1976) tidak bisa tercapai, akibatnya agency problem dan agency cost tidak dapat dikurangi.

Pada kondisi yang lain, tingkat kepemilikan oleh institusional (institusional ownership) yang merupakan pemegang saham dari unsur investor dan merupakan pemegang saham yang paling mendominasi struktur kepemilikan saham perusahaan-perusahaan go public Indonesia didominasi oleh perusahaan-perusahaan holding company yang saling berafiliasi bahkan para pemegang saham dari perusahaan-perusahaan holding company tersebut masih memiliki hubungan keluarga bahkan dengan pihak manajemen perusahaan (Sudarma, 2004 dalam Bambang Sugeng, 2009). Berdasarkan sampel perusahaan yang digunakan dalam penelitian ini yaitu 25 perusahaan, terdapat $45 \%$ atau sekitar 12 perusahaan yang merupakan perusahaan holding company. Dengan kondisi yang seperti ini, walaupun institusional ownership tergolong outsider ownership bersama dengan pemegang saham yang berasal dari public (masyarakat), namun dapat dikatakan status sebagai outsider dari institutional ownership tersebut menjadi semu, karena dalam kenyataannya mereka memiliki afiliasi yang kuat dengan manajemen, dengan kondisi seperti maka fungsi institutional ownership sebagai sarana monitoring terhadap manajemen tidak dapat berjalan secara efektiv akibatnya agency problem tidak dapat dikurangi. Atas dasar fenomena tersebut maka menarik untuk meneliti kembali sejauh mana struktur kepemilikan mempengaruhi nilai perusahaan.

Selain struktur kepemilikan, alternatif lain yang dapat dugunakan untuk mengurangi agency problem dan agency cost berdasarkan penelitian Jensen dan Meckling (1976) dalam A.W. Djabid (2009) adalah melalui keputusan keuangan 
yaitu kebijakan hutang dan kebijakan dividen. Kebijakan hutang berdasarkan agency theory dapat digunakan sebagai alternatif untuk mengurangi agency cost dan agency problem. Hutang dapat menurunkan agency cost karena hutang dapat menurunkan excess cash flow yang ada dalam perusahaan sehingga menurunkan kemungkinan pemborosan yang di lakukan oleh manajemen (Jensen dan Mecling, 1976 dalam Nasser, 2008). Dengan adanya debt yang besar manajemn berupaya meningkatkan laba agar perusahaan dapat membayarkan kewajibannya. Peningkatan hutang tersebut di kaitkan dengan meningkatnya harga saham dan penurunan hutang menyebabkan penurunan nilai perusahaan (Masulis, 1988 dalam Haruman, 2008).

Di lingkungan perusahaan go public di Indonesia, kebijakan struktur modal mereka pada umumnya menunjukan kondisi yang relatif unik. Dari keseluruhan sampel penelitian, diperoleh data tentang rasio leverage yaitu ratarata sebesar $45 \%$, bahkan berdasarkan data yang diperoleh tidak sedikit perusahaan memiliki rasio leverage di atas 50\%, hal tersebut menunjukan bahwa rata-rata setengah dari total nilai aset perusahaan dibiayai dari sumber dana utang bahkan tidak sedikit perusahaan yang justru lebih banyak menggunakan sumber dana utang dibanding modal sendiri. Berdasarkan agency theory (Jensen dan Meckling, 1976) penggunaan hutang akan meningkatkan nilai perusahaan, sedangkan menurut trade off model (Siaw, 1999 dalam Sjahrial, 2008) penggunaan hutang yang tinggi akan menyebabkan penurunan nilai perusahaan. Berdasarkan kondisi ini, maka menarik untuk meneliti sejauh mana kebijakan hutang mempengaruhi nilai perusahaan.

Keputusan keuangan lainnya yang digunakan untuk mengurangi agency problem dan agency cost menurut Jensen dan Meckling (1976) dalam A.W. Djabid (2009) adalah dengan kebijakan dividen yaitu dengan meningkatkan dividend payout ratio. Menurut A.W. Djabid (2009) pembayaran dividen akan membuat pemegang saham mempunyai tambahan return selain capital gain. Dividen juga membuat pemegang saham mempunyai kepastian pendapatan dan mengurangi agency cost of equity karena tindakan perquisites yang dilakukan manajemen terhadap cash flow perusahaan seiring dengan menurunnya biaya monitoring karena pemegang saham yakin bahwa kebijakan manajemen akan 
menguntungkan dirinya, dengan begitu nilai perusahaan akan meningkat. Namun di sisi lain, dengan semakin tingginya dividen yang dibagikan, mengakibatkan pendapatan yang diperoleh perusahaan makin banyak yang dialokasikan ke dividen dibandingkan ke laba ditahan. Laba ditahan yang rendah mengakibatkan kesempatan investasi menjadi berkurang. Di lain pihak, perusahaan dituntut untuk terus tumbuh. Dengan demikian untuk dapat melaksanakan investasi tersebut, maka kekurangan dana investasi dari laba ditahan dapat dipenuhi dari external financing yaitu dengan penggunaan hutang, namun penggunaan hutang ini akan menyebabkab meningkatnya resiko perusahaan terutama resiko kebangkrutan (Sjahrial, 2008).

Namun, keefektivan kebijakan hutang dan kebijakan dividen dalam rangka mengurangi agency problem dan dalam menciptakan nilai perusahaan tidak terlepas dari peran struktur kepemilikan khususnya insider ownership dan institutional ownership. Sebagaimana yang diungkapkan oleh Eastabrook (1984) dalam Sugeng (2009) menyatakan bahwa efektivitas dividen dan hutang sebagai salah satu sarana monitoring bergantung pada keberadaan saranasarana monitoring lainnya, dalam hal ini yaitu struktur kepemilikan.

Penelitian mengenai pengaruh struktur kepemilikan, kebijakan hutang, kebijakan dividend an nilai perusahaan dilakukan oleh Agus Harjito dan Nurfauziah (2006), Fatmawati (2008), Tendi Haruman (2008), Soesetio (2008), Nasser (2008), Bambang Sugeng (2009), A.W. Djabid (2009), Farah Margaretha dan Andhini Asmariani (2009) namun dari kesemua ini memiliki hasil yang berbeda-beda mengenai hubungan antara struktur kepemilikan saham, kebijakan hutang dan kebijakan dividen terhadap nilai perusahaan.

Berdasarkan uraian di atas, maka permasalahan yang akan di teliti di rumuskan sebagai berikut: Pertama, bagaimana pengaruh struktur kepememilikan saham terhadap kebijakan dividen perusahaan pada perusahaan yang terdaftar di Bursa Efek Indonesia. Kedua, bagaimana pengaruh struktur kepemilikan saham terhadap kebijakan hutang perusahaan pada perusahaan yang terdaftar di Bursa Efek Indonesia. Ketiga, bagaimana pengaruh struktur kepemilikan saham terhadap nilai perusahaan pada perusahaan yang terdaftar di Bursa Efek Indonesia. Keempat, bagaimana pengaruh kebijakan 
dividen perusahaan terhadap kebijakan hutang perusahaan pada perusahaan yang terdaftar di Bursa Efek Indonesia. Kelima, bagaimana pengaruh kebijakan dividen terhadap nilai perusahaan pada perusahaan yang terdaftar di Bursa Efek Indonesia. Keenam, bagaimana pengaruh kebijakan hutang perusahaan terhadap nilai perusahaan pada perusahaan yang terdaftar di Bursa Efek Indonesia.

\section{METODE}

Teknik analisis yang digunakan untuk pengujian hipotesis dalam penelitian ini adalah dengan menggunakan structural equation modeling(SEM). Dalam penelitian ini digunakan lebih dari satu indikator untuk mewakili satu variabel dan memiliki hubungan yang kompleks antara variabel-variabelnya sehingga peneliti menggunakan model persamaan struktural dalam penelitian kali ini. Adapun untuk tahapan penelitian dalam menganalisis factor-faktor agency theory yang mempengaruhi nilai perusahaan.

Penelitian ini menggunakan tiga variabel, yaitu: variabel endogen dalam penelitian ini diantaranya, kebijakan dividen $\left(\mathrm{Y}_{1}\right)$, kebijakan hutang $\left(\mathrm{Y}_{2}\right)$, dan nilai perusahaan $\left(\mathrm{Y}_{3}\right)$. Adapun yang menjadi variabel eksogen dalam penelitian adalah struktur kepemilikan $\left(\mathrm{X}_{1}\right)$. Variabel manifes dalam penelitian ini meliputi kepemilikan manajerial $\left(\mathrm{X}_{1.1}\right)$, kepemilikan institusional $\left(\mathrm{X}_{1.2}\right)$, Dividen

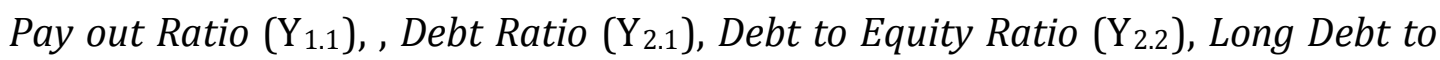
Equity Ratio $\left(\mathrm{Y}_{2.3}\right)$, Price Earning Ratio $\left(\mathrm{Y}_{3.2}\right)$, Market to Book Ratio $\left(\mathrm{Y}_{3.1}\right)$, Dividen Yield ( $\left.\mathrm{Y}_{3.3}\right)$, Tobin's $Q\left(\mathrm{Y}_{3.4}\right)$.

Salah satu tujuan SEM adalah menentukan apakah model plausible (masuk akal) atau fit. Suatu model penelitian dikatakan baik, apabila memiliki model fit yang baik pula. Uji signifikan dilakukan dengan cara melihat jalur-jalur pada model pengukuran dan model struktural. Pada model pengukuran, jalurjalur (pengaruh) yang dapat dilihat adalah jalur-jalur (pengaruh) yang menghubungkan antara variabel laten dengan indikatornya (variabel manifest), apakah mempunyai tingkat yang signifikan terhadap variabel latennya atau tidak. Serta pengujian terhadap hubungan antara variabel eksogen dengan variabel endogen. 


\section{PEMBAHASAN}

Sebelum melakukan pengujian terhadap hipotesis, maka sebelumnya perlu dilakukan pengujian goodness of fit terhadap model struktural yang telah dibangun serta uji evaluasi model Evaluasi ini dilakukan untuk mengetahui apakah model yang dibuat dalam penelitian mempunyai nilai fit yang baik atau tidak. Nilai fit suatu model dapat dilihat dari beberapa indikator goodness of fit index.

Setelah dilakukan pengujian fit model, maka langkah selanjutnya sebelum masuk ke dalam pengujian hipotesis maka terlebih dahulu dilakukan pengujian evaluasi model. Tahapan ini penting dilakukan karena untuk melihat dan menganalisis suatu indikator dalam mengukur variabel latennya dan untuk mengetahui seberapa besar proporsi varians yang dijelaskan oleh variabel latennya (sedangkan sisanya dijelaskan oleh measurement error) serta untuk melihat apakah seluruh jalur yang dihipotesiskan memiliki tingkat signifikansi yang baik atau tidak.

Berdasarkan hasil yang didapat terhadap nilai estimasi parameter serta nilai t-value dari jalur individual antara indicator terhadap variabel latennya, dapat disimpulkan secara keseluruhan variabel manifest (indikator) memiliki pengaruh yang signifikan terhadap variabel latennya, hal tersebut dapat dilihat dari nilai t-value (t-hitung) hubungan indicator terhadap variabel laten yang memiliki nilai lebih besar dari t-tabel yaitu sebesar 1.96. Sehingga dapat disimpulkan bahwa semua indikator memiliki kontribusi yang besar terhadap variabel latennya.

Dari output yang ditampilkan dengan path diagram dan ditunjukkan dengan tabel, maka didapatlah hubungan dan pengaruh sebagai berikut. Berdasarkan hasil pengujian terhadap pengaruh struktur kepemilikan terhadap kebijakan dividen menghasilkan koefisien path positif dan signifikan, ini dapat dilihat dari koefisien path sebesar 0.1144 dan nilai t-value sebesar 2.46 yang lebih besar dari |1.701|. Dengan demikian maka, $\mathrm{H}_{1}$ tidak tidak diterima.

Hasil ini tidak konsisten dengan agency teory (Jansen \& Meckling, 1976) yang menyatakan bahwa agency cost akan rendah di dalam perusahaan dengan kepemilikan manajerial (managerial ownership) yang tinggi, karena hal ini 
memungkinkan adanya penyatuan antara kepentingan pemegang saham dengan kepentingan manajer yang dalam hal ini berfungsi sebagai agent dan sekaligus sebagai principal. Dimungkinkan temuan ini terkait dengan karakteristik unik dari struktur kepemilikan dari perusahaan-perusahaan publik di Indonesia. Pertama, outsider's holding sebagian besar didominasi oleh institusional holding yang dalam kenyataannya terdiri dari perusahaanperusahaan holding company yang saling berafiliasi bahkan para pemegang saham dari perusahaan-perusahaan holding company tersebut masih berhubungan keluarga bahkan dengan pihak manajemen perusahaan (Sudarma, 2004). Rata-rata kepemilikan saham perusahaan oleh institusional secara keseluruhan mencapai $64.16 \%$ dan perusahaan dengan porsi institusional holding tertinggi mencapai 93.91\%. Kedua, porsi kepemilikan saham oleh manajerial sangat kecil, data yang ada menunjukan bahwa rata-rata kepemilikan oleh manajerial kurang dari 5\% sehingga praktis dianggap tidak tidak signifikan artinya adanya penyatuan antara kepentingan pemegang saham dengan kepentingan manajer tidak akan terwujud mengingat jumlah kepemilikan oleh manajerial sangat kecil, akibatnya agency cost dan agency problem tidak dapat ditekan.

Dengan struktur kepemilikan oleh pihak luar perusahaan yang yang demikian menunjukan bahwa mayoritas kepemilikan luar didominasi oleh pihak-pihak yang tidak independen (berafiliasi satu sama lain), akibat dari fenomena ini, institusi (perusahaan/lembaga) pemegang saham yang merefleksikan pemegang saham luar, tidak memiliki arti yang signifikan, dalam arti walaupun mereka sangat dominan tetapi karena mereka tidak independen satu sama lain termasuk dengan manajemen, maka pada hakekatnya mereka satu. Keadaan ini menyebabkan potensi agency problem antara pihak manajemen dengan pihak pemegang saham tidak signifikan sehingga mekanisme monitoring sebagaimana yang telah diungkapkan oleh Jensen \& Meckling (1976) tidak berjalan sebagaimana mestinya, dengan demikian perlu adanya pembayaran dividen payout yang tinggi untuk menggantikan fungsi kepemilikan sebagai monitoring yang tidak efektif untuk mengurangi agency problem dan untuk mengendalikan agency cost. 
Hasil olahan data selanjutnya menunjukan nilai koefisien path negatif dan signifikan antara struktur kepemilikan saham terhadap kebijakan hutang, hasil ini dapat dilihat dari koefisien path (loading) sebesar -0.0544 dan nilai thitung -2.679 lebih besar dari t-tabel sebesar |1.701|. Hasil ini menunjukan bahwa struktur kepemilikan berpengaruh negatif terhadap kebijakan hutang, artinya semakin tinggi struktur kepemilikan saham baik itu oleh pihak manajerial ataupun institusional maka penggunaan hutang oleh perusahaan akan semakin kecil. Dengan demikian maka $\mathrm{H}_{2}$ diterima.

Hasil temuan ini konsisten dengan agency theory (Jensen \& Meckling, 1976), dan juga penelitian yang dilakukan Moh'd, et.al. (1998) serta Bathala, et.al. (1994) dalam Tendi Haruman (2008), yang menyatakan bahwa struktur kepemilikan memiliki pengaruh signifikan dengan arah hubungan yang negatif. Meningkatnya kepemilikan saham oleh institusional ownership dapat mengimbangi kebutuhan terhadap hutang. Ini berarti bahwa institusional ownership dapat menggantikan peran hutang dalam memonitor manajer dalam perusahaan dan mengurangi agency problem. Dengan demikian semakin besar prosentase saham yang dimiliki oleh institusional ownership akan menyebabkan usaha monitoring menjadi semakin efektif, karena dapat mengendalikan perilaku opportunistic manajer dan memaksa manajer mengurangi tingkat hutang secara optimal sehingga akan mengurangi agency cost.

Berdasarkan hasil pengujian terhadap pengaruh struktur kepemilikan terhadap nilai perusahaan menghasilkan menghasilkan koefisien path negatif dan tidak signifikan, ini dapat ditunjukan dari koefisien path sebesar -0.01844 dan nilai t-hitung sebesar -0.2640 lebih kecil dari t-tabel |1.701|. Hasil tersebut menunjukan bahwa variabel struktur kepemilikan berpengaruh negatif terhadap nilai perusahaan, yang berarti semakin tinggi struktur kepemilikan saham perusahaan baik itu manajerial taupun institusional maka nilai perusahaan akan semakin menurun. Dengan demikian maka $\mathrm{H}_{3}$ tidak diterima.

Hasil temuan ini bertolak belakang dengan agency theory (Jensen \& Meckling, 1976), yang menyatakan bahwa semakin tinggi struktur kepemilikan dikuasai oleh pihak insiders (manajemen) maka semakin berkurang agency problem, karena semakin selarasnya antara kepentingan manajemen dengan 
kepentingan pemilik yang sebagian besar adalah manajemen sendiri, sehingga dapat meningkatkan nilai perusahaan. Begitupun dengan kepemilikan oleh institusional investor dapat mengurangi agency cost, karena dengan adanya kepemilikan saham oleh investor-investor institusional seperti perusahaan asuransi, bank, perusahan investasi dan kepemilikan oleh institusi lainnya dalam bentuk perusahaan akan mendorong peningkatan pengawasan (monitoring) yang lebih optimal terhadap kinerja insiders, sehingga dapat meningkatkan nilai perusahaan.

Namun hasil temuan ini mendukung penelitian yang dilakukan Etty M. Nasser (2008), Tendi Haruman (2008) dan Rahmawati dan Andi Febrian (2009), yang menemukan bahwa struktur kepemilkan berpengaruh negatif terhadap nilai perusahan. Menurut Tendi Haruman (2008) penurunan market value ini diakibatkan indikator fundamental tidak mencerminkan kondisi sebenarnya atau masih terjadi asimetri informasi. Hal ini berarti pula gagalnya manajer meyakinkan pasar atau tindakan yang dilakukan oleh para pemegang saham managerial tidak sejalan dengan keinginan pasar.

Berdasarkan penelitian Bambang Sugeng (2009), dimungkinkan temuan ini terkait dengan karakteristik perusahaan-perusahaan publik di Indonesia seperti yang telah di bahas pada hipotesis 1 , bahwa secara rata-rata proporsi kepemilikan saham manajerial relatif sangat kecil, menurut data rata-ratanya hanya 5\%, akibatnya tidak ada pengaruh yang signifikan fungsi manajerial dalam mengurangi agency problem, karena dengan kepemilikan yang rendah kemungkinan adanya penyatuan antara kepentingan pemegang saham dengan kepentingan manajemen tidak dapat terwujud. Di samping itu, karakteristik lain dari perusahaan Indonesia bahwa institusional ownership (kepemilikan lembaga) dari perusahaan-perusahaan holding companies yang saling berafiliasi bahkanmasih merupakan perusahaan-perusahaan keluarga dimana pihak manajemen perusahaan masih bagian dari perusahaan-perusahaan keluarga tersebut (Sudarma,2004) dalam Bambang Sugeng (2009). Sehingga walaupun kepemilikan saham oleh pihak outsiders dalam hal ini institusional ownership tinggi, karena didominasi oleh pihak-pihak yang tidak independen (berafiliasi satu sama lain), akibatnya fungsi institusional ownership sebagai mechanisme 
monitoring bagi manajemen tidak bisa berjalan semestinya, sehingga agency problem tidak bisa ditekan, dan akhirnya berimbas pada market value perusahaan yang menurun.

Hasil pengujian terhadap hipotesis empat, berdasarkan path diagram diatas menunjukan bahwa pengaruh kebijakan dividen terhadap kebijakan hutang menunjukan nilai koefisien path negatif dan tidak signifikan, hal ini dapat dilihat dari koefisien path sebesar -0.0563 dan nilai t-hitung sebesar 1.318 yang lebih kecil dari t-tabel. Hasil tersebut menunjukan bahwa variabel kebijakan dividen tidak berpengaruh terhadap kebijakan hutang. Dengan demikian maka $\mathrm{H}_{4}$ tidak diterima.

Hasil temuan ini tidak mendukung hasil penelitian Jensen et.al., (1992) dan Moh'd et.al.,(1998) dalam Tendi Haruman (2008) yang menyatakan bahwa dividen payout memiliki pengaruh yang signifikan dan berhubungan negatif terhadap debt ratio. Namun arah hubungan (tanda koefisien) yang dihasilkan sesuai dengan agency cost models (Jensen et.al., 1992), yang menyatakan bahwa pembayaran dividen muncul sebagai pengganti hutang di dalam struktur modal untuk mengawasi prilaku manajer. Dalam konteks ini, perusahaan yang memiliki dividen payout ratio yang tinggi lebih menyukai pendanaan dengan modal sendiri sehingga mengurangi agency cost of debt.

Argumen lain yang mengarah kepada hubungan negatif kedua variabel adalah bahwa pembayaran dividen yang tinggi akan memperbesar beban tetap perusahaan sehingga menyebabkan hutang lebih berisiko dan karenanya akan menurunkan nilai dari hutang tersebut (Taranto, 2002 dan Noronha,1996) dalam Sugeng (2009).

Hasil penelitian yang tidak signifikan ini mengintrepestasikan bahwa para manajer dari perusahaan-perusahaan go public di Indonesia relatif tidak mengindahkan potensi risiko financial distress akibat tingginya financial leverage. Tendensi prilaku manajer demikian diindikasikan pula melalui bukti lainnya yang menunjukan bahwa rata-rata resiko leverage dari perusahaanperusahaan dalam sampel penelitian selama periode penelitian 2006-2009 untuk DER-nya yaitu mencapai $45.2 \%$. Ini berarti kurang lebih $45.2 \%$ atau hampir separuh dari total aset perusahaan dibiayai dari sumber hutang. Namun 
berdasarkan data yang ada tidak sedikit jumlah perusahaan memiliki rasio leverage di atas 50\%, artinya sebagian besar dari aset perusahaan bersumber dari dana utang. Bahkan perusahaan dengan rasio leverage tertinggi mencapai $84 \%$ yang berarti hampir seluruhnya aset perusahaan dibiayai hanya dari sumber hutang. Tingginya rasio leverage di lingkungan perusahaan-perusahaan go public di Indonesia menunjukan tingginya risiko yang sebenarnya mereka hadapi terutama resiko terhadap terjadinya kesulitan finansial (financial distress) hasil ini didasarkan atas penelitian yang dilakukan oleh Bambang Sugeng (2009).

Berdasarkan hasil pengujian terhadap pengaruh kebijakan dividen terhadap nilai perusahaan menghasilkan koefisien path negatif dan tidak signifikan, ini dapat dilihat dari koefisien path (faktor loading) sebesar -0.363 dan nilai t-hitung yang lebih kecil dari t-tabel yaitu sebesar -1.6705. Hasil tersebut menunjukan bahwa kebijakan dividen tidak berpengaruh terhadap nilai perusahaan. Dengan demikian maka $\mathrm{H}_{5}$ tidak diterima. Hasil ini tidak konsisten dengan agency teory (Jansen \& Meckling, 1976) dalam Bambang Sugeng (2009) yang menyatakan bahwa kebijakan dividen digunakan untuk meminimalisi agency cost yang timbul dari potensi conflict of interest antara agen (manajer) dengan principal (pemilik perusahaan) akibat adanya pemisahan antara kedua belah pihak tersebut. Dasar dari agency cost models ini adalah ketika manajer disadari bisa bertindak tidak sesuai dengan kepentingannya investor/pemegang saham, maka pemegang saham menggunakan mekanisme tertentu untuk mengontrol tindakan manajer tersebut, salah satunya adalah melalui pembayaran dividen dengan payout yang tinggi (Beiner, 2001) dalam Sugeng (2009). Namun, efektivitas dividen sebagai salah satu sarana monitoring bergantung pula pada keberadaan sarana-sarana monitoring lainnya, misalnya struktur kepemilikan dan kebijakan hutang (Eastabrook, 1984 dalam Sugeng, 2009).

Berdasarkan hasil menunjukan adanya koefisien path positif dan signifikan antara kebijakan hutang terhadap nilai perusahaan, ini dapat dilihat dari koefisien path (factor loading) sebesar 0.7827 dan nilai t-hitung sebesar 2.0116 yang lebih besar dari t-tabel sebesar |1.701|. Hubungan tersebut 
menyatakan bahwa variabel kebijakan hutang berpengaruh positif terhadap nilai perusahaan, artinya semakin tinggi penggunaan hutang oleh perusahaan maka nilai perusahaan semakin meningkat. Dengan demikian $\mathbf{H 6}$ diterima.

Hasil temuan ini konsisten dengan agency theory (Jensen dan Meckling, 1976), yang menyatakan bahwa kebijakan hutang berpengaruh positif dan signifikan terhadap nilai perusahaan. Menurut Jensen dan Mecling (1976) dalam Nasser (2008) salah satu alternatif yang digunakan untuk mengurangi agency cost adalah dengan meningkatkan pendanaan dengan hutang. Peningkatan utang akan menurunkan besarnya konflik antara pemegang saham dengan manajemen, disamping itu akan menurunkan axcess cash flow yang ada dalam perusahaan sehingga menurunkan kemungkinan pemborosan yang dilakukan oleh manajemen. Peningkatan hutang tersebut dikaitkan dengan meningkatnya harga saham perusahaan sedangkan penurunan hutang akan menurunkan harga saham perusahaan. Dengan demikian hipotesis yang ke-6 ini mendukung agency theory, dan juga memperkuat hasil penelitian sebelumnya yang dilakukan oleh Nasser (2008) yang menemukan bahwa kebijakan hutang berpengaruh positif dan signifikan terhadap nilai perusahaan.

\section{SIMPULAN}

Struktur kepemilikan berpengaruh positif signifikan terhadap kebijakan dividen. Hal ini berarti semakin tinggi struktur kepemilikan saham perusahaan baik itu oleh insider ownership ataupun institusional ownership berpengaruh pada meningkatnya pembayaran dividen (dividen payout). Struktur kepemilikan berpengaruh negatif signifikan terhadap kebijakan hutang. Hal ini berarti peningkatan struktur kepemilikan perusahaan berpengaruh terhadap penurunan hutang perusahaan.

Struktur kepemilikan tidak berpengaruh terhadap nilai perusahaan. Hal ini berarti peningkatan terhadap struktur kepemilikan saham tidak berpengaruh terhadap nilai perusahaan. Kebijakan dividen tidak berpengaruh terhadap kebijakan hutang. Hal ini berarti bahwa setiap kenaikan atau penurunan dividen yang dibayarkan (dividen payout) kepada investor tidak berpengaruh terhadap hutang perusahaan. 
Kebijakan dividen tidak berpengaruh signifikan terhadap nilai perusahaan. Hal ini berarti peningkatan atau penurunan dari pembayaran dividen (dividen payout) tidak berpengaruh terhadap nilai perusahaan. Kebijakan hutang berpengaruh positif signifikan terhadap nilai perusahaan. Artinya, semakin tinggi penggunaan hutang oleh perusahaan maka akan berpengaruh terhadap meningkatnya nilai perusahaan.

\section{PUSTAKA ACUAN}

Ayres, I. \& P. Cramton. 1994. Relational Investing and Agency Theory. Cardozo Law Review, Vol.15. pp. 1033-1040.

Brealey, M \& Marcus. 2008. Dasar-dasar Manajemen Keuangan Perusahaan, Jilid 1. Jakarta: Erlangga.

Brigham \& Houston. 2009. Fundamentals of Financial Management. Jakarta: Salemba Empat.

Bodie, K. \& Marcus. 2006. Investments. Jakarta: Salemba Empat.

Brigham \& Houston. 2001. Manajemen Keuangan. Jakarta: Erlangga.

Djabid, A. 2009. Kebijakan Dividen Dan Struktur Kepemilikan Terhadap Kebijakan Hutang: Sebuah Perspektif Agency Theory. Jurnal Keuangan dan Perbankan, Vol.13, No.2, Mei 2009.

Ghozali, I \& Fuad. 2008. Structural Equation Modeling (Teori, Konsep dan Aplikasi dengan Program Lisrel 8.80). Semarang: BP Universitas Diponogoro.

Harjito, D.A. 2006. Hubungan Kebijakan Hutang, Insider Ownership, Dan Kebijakan Dividen Dalam Mekanisme Pengawasan Masalah Agensi Di Indonesia. JAAI, Vol.11, No.2, Desember.

Haruman, Tendi. 2008. Struktur Kepemilikan, Keputusan Keuangan dan Nilai Perusahaan. Jurnal Keuangan dan Perbankan, Vol.10 No.2, Desember, 2008.

Heinfeldt, J. \& R. Curcio. 1997. Employee Management Strategy, StakeholderAgency Theory and The Value of the Firm. Journal of Financial and Strategic Decision", Vol.10, No.1.

Cristiawan, Y.J. \& T. Josua. 2007. Kepemilikan Manajerial: Kebijakan Hutang, Kinerja, dan Nilai Perusahaan. Jurnal Akuntansi dan Keuangan, Vol.9, No.1,Mei. 
Keown, S. et.al. 2000. Dasar-asar Manajemen Keuangan. Jakarta: Salemba Empat.

Margaretha, F. \& A. Asmariani. 2009. Faktor-Faktor Agency Theory yang mempenaruhi Hutang, Media Riset dan Bisnis, Vol.9 No. 1, April, pp.120.

Margaretha, F. 2008. Pengaruh PER, Dividen Yield, dan MBR terhadap Stock Return di BEI. Jurnal Bisnis dan Akuntansi. Vol.10, No.3, Desember..

Moeljadi. 2006. Manajemen Keuangan pendekatan kualitatif dan kuantitatif jilid 1. Malang: Bayumedia.

Hanafi, M.M. \& A. Halim. 2009. Analisis Laporan Keuangan. Yogyakarta: UPP STIM YKPN.

Nasser, E.M. 2008. Pengaruh Struktur Kepemilikan dan Dewan Komisaris Independen Terhadap Nilai Perusahaan dengan Manajemen Laba dan Kebijakan Hutang sebagai Variabel Intervening. Media Riset Akuntansi, Auditing, dan Informasi, Vol.8, No.1, April.

Nasarudin, I. \& U. Maimunah. 2009. Pengaruh Struktur Kepemilikan Saham, Struktur Modal, Faktor Intern dan Faktor Ekstern, terhadap Nilai Perusahaan. Etikonomi, Vol.8, No.1, April.

Rahmawati \& A. Febrian. 2009. Pengaruh Corporate Governance terhadap Nilai Perusahaan. Etikonomi, Vol.8, No.2, Agustus.

Ramadhan, T. 2009. Pengaruh Kepemilikan Manajerial dan Kepemilikan Institusional terhadap Kebijakan Hutang pada Perusahaan Manufaktur di BEI 2004-2006., (Skripsi Tidak Dipublikasikan). Surakarta: Universitas Muhamadiyah Surakarta.

Rodoni, A. \& H. Ali. 2010. Manajemen Keuangan. Jakarta : Mitra Wacana Media.

Safrida, E. 2008. Pengaruh Struktur Modal dan Pertumbuhan Perusahaan terhadap Nilai Perusahaan pada Perusahaan Manufaktur di Bursa Efek Indonesia. (Tesis Tidak Dipublikasikan). Medan: Universitas Sumatra Utara.

Atmaja, L.S. 2008. Manajemen Keuangan (Teori \& Praktek). Yogyakarta: CV. Andi. Sjahrial, D. 2008. Manajemen Keuangan Edisi 2. Jakarta: Mitra Wacana Media. 
Sugeng, B. 2009. Pengaruh Struktur Kepemilikan \& Struktur Modal Terhadap Kebijakan Inisiasi Dividen Di Indonesia. Jurnal Ekonomi dan Bisnis, Vol. 14, No. 1.

Surya, I. \& I. Yustiavandana. 2008. Penerapan Good Coorporate Governance. Jakarta: Kencana Prenada Media Group.

Yuhasril. 2006. Analisis Faktor-Faktor Yang Mempengaruhi Struktur Modal Perusahaan Farmasi Yang Telah Go Public Di Bursa Efek Jakarta. BULLETIN Penelitian No.09. 